\title{
West German State Newsreels in the Period of the Economic Miracle 1950-1964
}

\author{
Gender as an Open Approach
}

\section{UTA SCHWARZ}

\begin{abstract}
"Bears and fashion shows were enjoyed the best. Korean theatre of war was too short."1
\end{abstract}

Because societies are founded on communication, social historians of the 20 th century are studying mass media, its role, function and impact in the social process, its contents, discourses and images, and how production and reception can be understood. Gender is one major analytical category of social history. It aims to study the social constructions of the sexes in their interdependency and related to economic, cultural and other contextualizing factors. Gender relations are considered socially constructed through cultural means and practices, for example by mass media; and like mass media, gender relations develop in the process of social change.

Studying Germany's social history in the two decades after Second World War, the gender studies approach proves particularly appropriate. In Germany, war and post-war experiences profoundly marked men and women and put into question pre-war concepts of masculinity and femininity. In

1 Cinema owner from Osnabrück, reporting audience's reaction to NEUE Deutsche Wochenschau Nr. 22, August 1950 (quoted in: Schwarz 2002: 437, translated by the author). 
the first years after the war, contemporaries observed a disastrous "crisis of shame" in heterosexual sexual life, referring to experiences of rape and prostitution, illegitimate sex and abortion, sexual problems within families and divorce, relations of young women with allied soldiers, and venereal diseases (Eder 2008: 11 et seqq., translated by the author).

Like newsreel studies, gender analysis is adapted to the heterogeneity of its object, providing methodological openness. It incorporates aspects of film history, media history, social history, British cultural studies, the French Annales School and other epistemological orientations in order to grasp newsreels as an integral part of the cinematographic culture of entertainment and consumption, which in its heterogeneous character and overall composition can be understood as an effective strategy of social engineering. The concept that gender difference is a construction urges the researcher to proceed from the analysis of the film itself and to include in the analysis not only the cognitive content of images and discourses, but also the sensual communication qualities of the media product, its spoken and written text, moving image and sound and how these facets are related to, rather than proceed from, a knowledge constructed otherwise.

The first gender studies analysis of the Federal Republic of Germany's (FRG) state newsreel 1950-1964 (cf. Schwarz 2002) combines an analysis of the newsreel as program including sensual aspects and symbolic representations, taking into account the content of images and associated meanings in relation to actors and discourses (cf. Chartier 1989). The study also incorporates a reconstruction of the political and economic backgrounds from paper archives, and a survey of contemporary facts and fictions about the newsreel's reception.

This article will adopt a more distant attitude. Inspired by recent publications in feminist theory and political communication studies, both referring to Michel Foucault's central notion of the dispositif and subsequent interpretations, I will look to the same object-the FRG's state newsreel in the long decade of 1950 s - with a different focus. My intention is to observe where power and resistance appeared in the realm of newsreel and how it can be described.

Foucault stressed the productivity of power since the era of enlightenment, in contrast to its more repressive nature in pre-modern times. A dispositif (in the following quote translated as apparatus) is defined as a strategically oriented entity combining elements of heterogeneous nature, "dis- 
courses, institutions, architectural forms, regulatory decisions, laws, administrative measures, scientific statements, philosophical, moral and philanthropic propositions ... The apparatus itself is the system of relations that can be established between these elements." (Foucault 1980: 194). In this sense, the newsreel as well as the gender system are dispositifs, although the French philosopher himself never considered gender as such (cf. King 2004: 29 et seq.). However, feminist reception of Foucault has appropriated the term as useful for analyzing gender difference, subjection and resistance (cf. Leache 2011: 16-18). For the period studied, newsreel and the gender system, in close and strategic interconnectivity, were operating on differences and hierarchies, producing effects and distinctions of normality and a-normality.

The feminist claim of the 1970s that "the private is political" challenged institutionalized politics' exclusive representation of the political; ecology and new social movements followed. In a society constructed by and through communication, media are the genuinely political, structured by strategic regimes of "what can be said and seen". Jacques Rancière's formula of the media as a "police" regime, acting via a "distribution of the sensual", points to the disposing and gate-keeping function of media, as they admit to or bar from the realm of sensual perception, in which is defined what is common and what remains excluded, a realm whose strategic rationale or purpose is "the right apportionment of bodies in the community" (Rancière 2006: 25 et seqq., translated by the author; cf. Sieber 2012: 44 et seqq.). Insofar as this realm of sensual perception also contributes to form subjectivities, it stresses spatial, sensual, and relational aspects in the process of subjectivity-formation which have been described by Foucault as a product of discourses. The sensual also links to the concept of representation, where the image is seen as a sensual, ambiguous, associative and emotionally appealing element (cf. Diehl 2012: 163).

In the section that follows, the newsreel's formal aspects are highlighted in relation to gender and national identity; following this, examples are given of typical codes and imaginary operations. 


\section{Government's NeWSREels of "PatRiarchal DEMOCRACY" AND "ECONOMIC MIRACLE"}

When the Federal Republic of Germany (FRG) was established in 1949, in West Germany and West Berlin a newsreel "market" re-emerged. Two American newsreels, WELT IM FILM (THE WORLD IN MOTION PICTURE, produced by the US Armed Forces) and Fox TÖNENDE Wochenschau (FOX SOUND NEWSREEL, produced by $20^{\text {th }}$ Century Fox), and the former French occupation newsreel transformed into a German company BLICK IN DIE WELT [VIEW INTO THE WORLD] competed on this territory. The German side, in a situation of restricted sovereignty, did not want to be at the mercy of the allied powers in matters of newsreels; also it seemed important in West German eyes, not to leave "Germany's" audio-visual representation abroad to the German Democratic Republic's (GDR) newsreel DER AugenZeuge (THE EYE WitnESS).

The initiative to establish a NeuE Deutsche Wochenschau [NeW GERMAN NEWSREEL] came from the film and newsreel milieu in Hamburg, linked to local social democrat elites. When the British Armed Forces withdrew in 1949 from the joint Anglo-American military occupation newsreel, they supported the German project in order not to leave their newsreel distribution potential to the Americans. Konrad Adenauer's liberalconservative government in Bonn joined the project and benefitted from its initial financial difficulties. Within barely two years, the Federal State owned the newsreel production company, and the chancellor, as the state's executive head, could "fully exploit" it (von Hase 1988: 99 et seqq.). The newsreel became part of what has been called the "chancellor's democracy" (Wolfrum 2004: 177, translated by the author). In 1956, with box offices earning their highest rates ever (817,5 Mio), every week about 9,5 million cinema-goers saw one of the two state-owned newsreels: NEUE DEUTSCHE WoChENSCHAU (NDW) and WeLt IM BILD (WiB). Between 1952 and 1962 and during the "economic miracle", two thirds of West Germany's and West Berlin's cinema theatres screened one of the reels weekly as part of their pre-program. Cinema audiences in this long decade were composed principally of young people, children, and young unmarried adults, among them clearly more men than women (cf. Prommer 2010: 235-237). Particular enthusiasm for the newsreel came from young people 12 to 16 years old and woman over 50 (cf. Hagemann 1958: 12). 
This political frame may suggest that the state-owned newsreels were mouthpieces of the government: "some people joked that it was just installed to avoid the necessity of creating a new Ministry of Propaganda" (Griep 1996: 159f). The following paragraphs will explore along which criteria the sensual was divided up in/by the newsreel.

A standard newsreel filmstrip of 300 meters $(35 \mathrm{~mm})$ ran for eleven minutes on the screen, encompassing ten to thirteen elements (later six to eight longer sujets). On the content level, the newsreels integrated filmnews from heterogeneous spheres: from the national and the international; from politics and cinema; from economy and sports; from industry and leisure time. Fig. 1 shows how in the arrangement of stories from home and stories from abroad difference is constructed in weekly editions of the NDW composed by single film-news. The graphical scheme depicts the apportionment of the sensual at work: program placement, the length of single films and their succession were arranged along the national-internationaldifference. According to this routine in arrangement, the letterhead slogan on NDW archive documents_- "Der Filmbericht, der unsere Sprache spricht." [The film report speaking our language.] - conveyed an audiovisual Gestalt to the imagined relations between a national 'we' and the international 'other'. The initially casual practice of starting with national politics and ending with national sports became a rule at least from summer 1952, when the NDW was urged by the government to provide support for its politics. Both topics were given relatively significant amounts of time, and especially national politics were given more narrative depth and cinematographic space than film-news from abroad.

An allocative logic of "we" and "others" also proves to be valid if we look at the NDW and WiB content with gender-sensitive eyes (see Fig. 2). Subjects in which the main actors are not men (fashion, celebrities, beauty contests; gorilla as a painter) were located in the intermediate space of an edition, very often at its end, before sport stories (mostly German) started. Going through editions over the years, this pattern proves valid, though with manifold variations, at least in the first half of the 1950s: film-news with women appearing in active parts are to be found more often in-or more exactly, at the end of - the middle part of the "Auslandsberichte" [reports from abroad]. On the other hand, in film-news shot at home, women were hardly to be found as actors. 
Fig. 1: Program composition by nationally produced and imported sujets. NEUE DEUTSCHE WOCHENSCHAU 1950-1955.

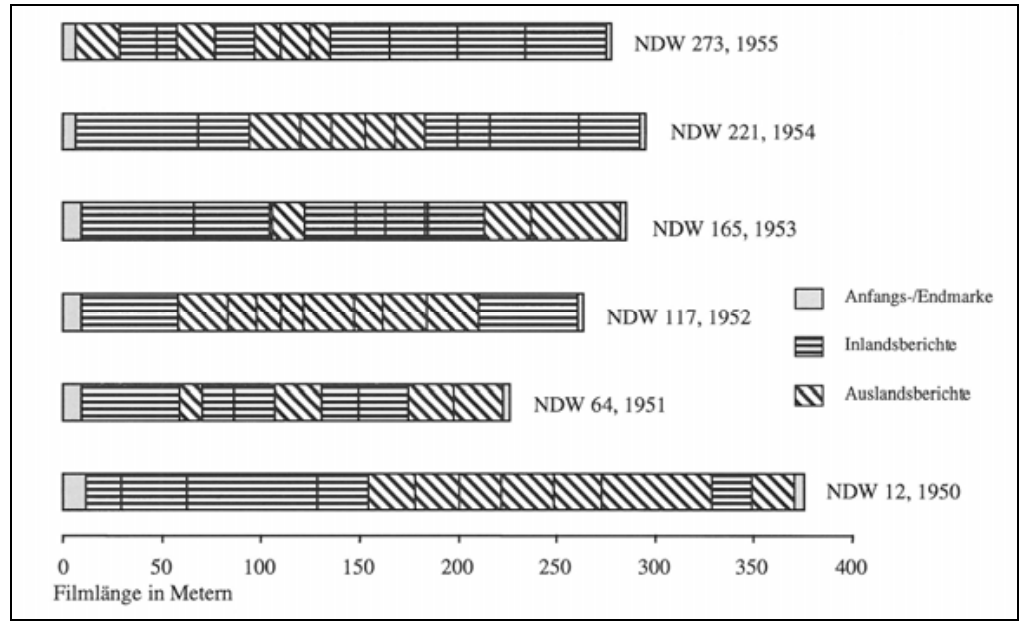

Source: Author's illustration

Fig. 2: Program places of topics. NEUE DEUTSCHE WOCHENSCHAU 19501952-1959.

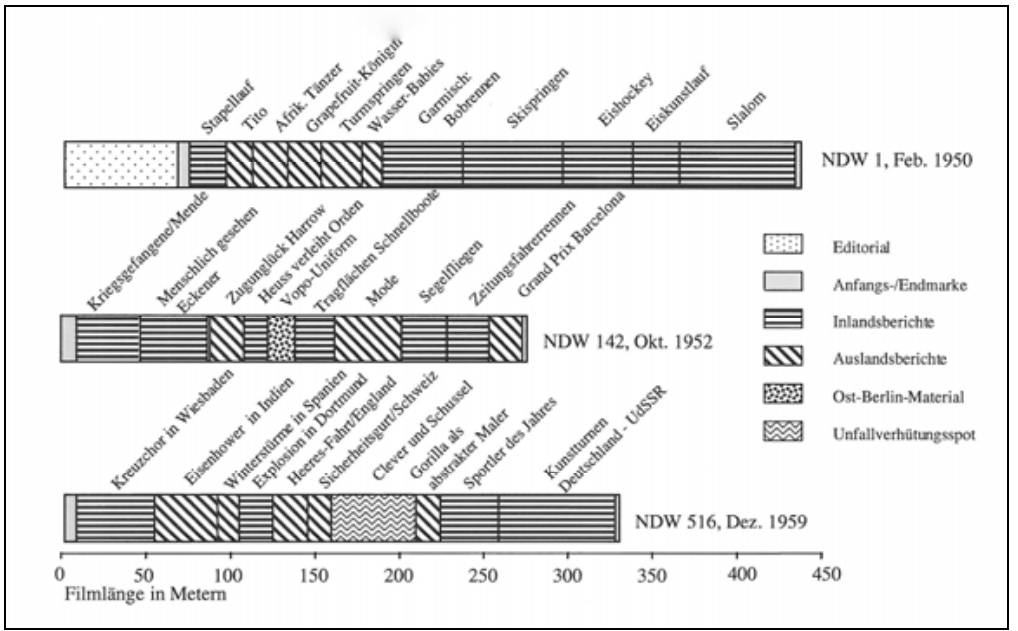

Source: Author's illustration 
If we read the newsreel arrangement as the narrative of an imaginative trip around the world offered to the cinema audience, then this trip starts in a more or less well established or optimistic home, goes through social problems, catastrophes, crisis or misery abroad as well as through erotic/exotic spheres, after which women (or something "other than male") appears just before re-entering the home area through sports. One can't help but recognize in this storyline what feminist film theory described in the classic fictional cinema: The female figure is waiting in the area of action, indicating the place of the hero's destination, warranting the narrative enclosure and subordinating herself to the male view. "She confirms the mythic subject" (Gottgetreu 1992: 44 et seqq., translated by the author). Classical cinema's "information format" shared this gendered narrative, while production companies' and political stakeholders' discourse stressed the newsreel's informative character.

"Auslandsberichte" [reports from abroad] were shorter, located in between and compiled in higher quantity and bandwidth of heterogeneity. Therefore they could attract less attention, and a contextualizing reception of the single event information was barely possible. The high degree of variety_ of world regions, social and cultural levels and spheres-was knit together in a fugacious flow and coupled with a strong stereotyping in the choice of reported events and how they had been recorded. In some sense, the newsreel repeated already "known", iconified images from abroad: Blizzards, rodeos, celebrities or military issues from the USA; strikes or fashion from France; the royal families from England and the Netherlands; earthquakes from Asia; from Africa conflicts of de-colonization or black men dancing for a European king at a diplomatic event. The "other" appeared familiar and not in the least unsettling.

This "deoxidizing" aspect (on the level) of content is counterbalanced by a strategy of affect and emotional manipulation on the level of arrangement. As former members of NDW's production team assert, a weekly edition was considered perfect when it offered the audience an alternating bath of feelings (cf. Schwarz 2002: 151). In Aristotle's rhetoric, delight and pain are the main vectors of exciting the public into the state of affect: beside cognition, imagination and physical experience are addressed, and the transfer of feelings is made by voice, rhythm, diction and bodily commitment of the orator (cf. Diehl 2012: 160 et seqq.). Newsreel producers shared a knowledge of cinematographic rhetoric in their common produc- 
tive practice, an intuition regarding how the program had to be composed in order to take the audience on an emotional rollercoaster ride and generate knee-jerk reactions of consternation, amusement or loud laughing. In filmnews on sports, such as soccer matches, the newsreel camera demonstratively took close-ups from on-location-spectators, frantic or giddy with pleasure-a giddy and self-reflexive spectacle of being 'beside oneself'. This mood management 'formula' coincided with the aims and interests of different stakeholders: of cinema goers eager for information of the rest of the world or just awaiting the fictional main attraction; of cinema owners demanding the audience's mood management from pre-program to the complete darkness of the fiction film; and of the political class investing in a widely accepted product for shaping opinions to gain acclamation and votes.

This mood management technique relied on a thoroughly gendered practice. A study published by UNESCO in 1951 entitled Newsreels across the world described the format's structure along degrees of emotionality as actuality: from eruptive "sudden events of immediate interest" with a disphoric emotional appeal (catastrophes, strikes etc.), to "scheduled events" prepared by the public relation units in politics, industry, sports and fashion with a moderate emotionality, and to "items of general interest" (traditions and habits, pin-up-Girls, children, animals) which could be used as fillers because of their ritualized, time-detached character (Baechlin/Muller-Strauss 1951: 19). The "items of general interest"-with actors other than men, in both senses of the word-must have been considered especially euphoric and indispensable to assure the mood shift. Their pragmatic location towards the end of the international middle section of the newsreel was essential to ensure the audience's emotional transfer towards the re-creative realms of fictional cinema.

The discourse around the newsreel was situated around the idea of audio-visual frontier crossing as a negotiation of power related to identity. Manifold conflicting intentions and contradictory projections were captured as in a hall of mirrors. With the advent of sound, the United States had become the leading nation in this market, beside British and French companies, and their newsreels attained a global hegemony in news-film business and coverage, criticized by UNESCO in 1951 as "a virtual world monopoly" (Baechlin/Muller-Strauss 1951: 17). Against the preponderance of newsreel companies controlled from abroad on FRG's territory, the German 
side wanted a national newsreel to demonstrate sovereignty ${ }^{2}$, autonomy from foreign influence, and of being part of the news-film exporting nations. In early FRG the film production branch and the political class, driven both by economic motives and the idea of the film's persuasive power, agreed to re-appropriate cinematographic means. In the first session of NDW's supervisory board two targets were identified: the newsreel should be the nation's promotion tool for the exportation of industrial goods, and the newsreel should realize and express the idea of national sovereignty, as the power to design the nation's image abroad. It should make sure that "foreign countries, via the exchange of images, will get to see events from all realms of public life in Germany through German eyes" (quoted in: Schwarz $2002^{3}$ : 80 et seqq.). Beside the more pragmatic exportation argument, the cinematographic argument referred to an international process of (self-)display and "being-looked-at", needing control over the nation's image abroad. Interestingly, the newsreel's persuasive power at home remained unexplored, invisible to the daylight discourse.

Cinema-goers' demand for film-news from all over the world, historically linked to the advent of photography, radio and cinema, had been systematically developed. In the 1920s an exchange between German and American newsreel-producing companies had started, interrupted during the war. ${ }^{4}$ When in the spring of 1950 a young NDW was struggling in the German newsreel market, cinema-goers criticized "that most actual events from abroad are missing and too much unimportant events from Germany are shown" (quoted in: Schwarz 2002: 433). Indeed, the first production from NDW, released in February 1950, had been composed of 74 percent homemade material, as exchange with foreign agencies was still a work in progress. But it was more: Cinema-goers and cinema-owners in the FRG did not expect the format of the newsreel to be a national one.

2 The Besatzungsstatut [Occupation Statute, Mai 1949] transformed allied military occupation of West Germany into a limited sovereignty for the future West German state, notably in terms of demilitarizing, foreign politics and trade.

3 To increase readability, all direct quotes taken from my German texts (cf. Schwarz 2000; 2001; 2002; 2003; 2006) have been translated to English.

4 During the war, foreign and entertaining news-films were banned from the DEUTSCHE WochenschaU. In 1945 allied occupation forces started to screen foreign film-news especially from the States. 
Fig. 3: "The first independent newsreel in 17 years ". NEUE DEUTSCHE WOCHENSCHAU Nr. 1, 1950.

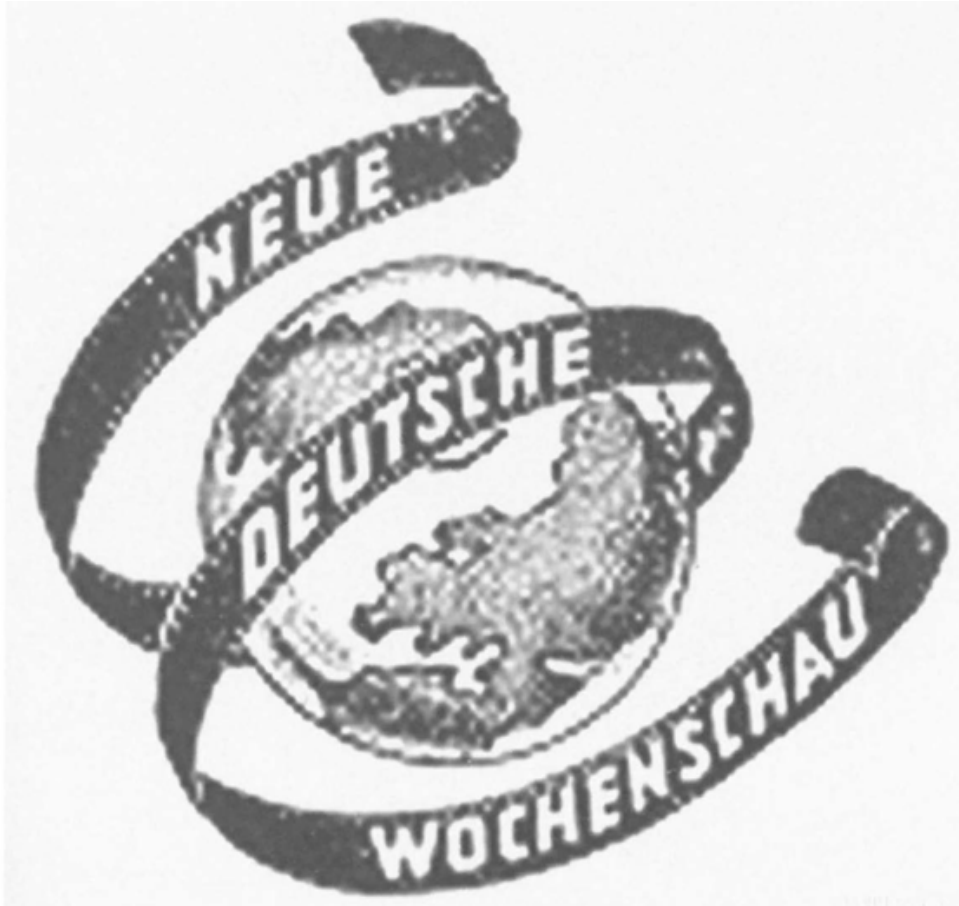

Source: Bundesarchiv

The production team intended to realize a newsreel recognizable as "new" and as "German" from its content, point of view and aesthetic features. However, NDW's editorial line of constructing national identity, seemingly appropriate at the moment of nation-building to attract a national audience, did not meet with unanimous approval. Cinema owners and audiences felt that NDW's opening (and closing) credits were too old-fashioned and weak in graphics and musical theme, compared to the broad, globe-covering graphics and extroverted acoustic air of the British-American WELT IM FILM. Disappointed, a cinema-owner complained: "The opening credits, the crossover between single sujets and the overall arrangement do not compete with WELT IM FILM" (Schwarz 2002: 433). NDW's initial aesthetical 
"German-ness" 5 did not correspond to the modern aesthetic sensibility and communicative performance the audience had learned over the course of decades and refreshed over the five years of the allies' WELT IM FILM from 1945-49. Competing at the level set by international standards demanded a speaker's self-conscious vocal acting in an attitude of modernity, accessing the world with sincerity and optimism. Finally, through subtle improvements and adaptations - and along with a new special topic starting in summer 1950, USA's war in Korea-NDW succeeded in being accepted and even acclaimed by the local audiences. Notably, this success was the result of NDW's pacifist commentaries on the war images. ${ }^{6}$

Newsreel audiences and cinema owners, asked what they liked most about NDW and WiB, expressed a strong preference for commentaries. The most important purpose of newsreel's spoken commentary was to build discursive bridges from one sujet to the other. Especially in the middle section of a newsreel, the commentary had to provide transitions, organizing the heterogeneous spheres into a unified perspective. This linking function was one of the speaker's essential and identification-triggering functions. In 1959, a distribution agent described the ideal commentary in terms of performativity as having a "smoothness and a causerie's elegance" (quoted in: Lehnert 2013: 287, translated by the author).

It was an ideal reception, the view of a flâneur: the capacity to perceive fast-moving, highly divergent images from all over the world, and to draw from the visual maelstrom, the back and forth of fascination and distance, a subjective and commensurable sense, articulated in ordered phrases in the national language. This answer to the "feaze of image collections" (Kracauer 1927a: 198, translated by the author) seems to have been one of the most important factors in terms of encouraging collective identification. The speaker had to utilize appropriate words and diction for a personal but collectively acceptable negotiation of allurements, threats, and thoughts possibly emanating from the images. His experienced but somehow locally

5 Most NDW cameramen, the cutter-in-chief and the editor-in-chief had been members of the NS war newsreel or propaganda companies.

6 Two years later, responsible editor-in-chief Heinz Kuntze-Just was dismissed on demand of the American High Commission. His pacifist commentaries on USA's war in Korea were considered an obstacle for West Germany's rearmament. 
specific speech provided a linguistic translation of the voyeuristic attitude towards the "others", and this was the spectacle the audience was seeing and listening to. The tone may seem to us today "announcing"-but for contemporaries this preaching way of speaking was necessary and adapted to cinema halls with more than 1000 seats: the architecture's contribution to the newsreel dispositif, one of information, not of communication (cf. Sieber 2012: 45). The most famous NDW speaker was Hermann Rockmann from the NORDWESTDEUTSCHER RUNDFUNK public radio station in Hamburg. Every week when recording the commentary in the NDW studio, he immersed into the ocean waves of the already adjusted film-news stories emotionally enhanced by music added from the archive. Reading commentary well prepared by the editor-in-chief, Rockmann emerged from that ocean without being absorbed, and the following Friday it was the audience's pleasure to witness his struggle from a comfortable seat in the dark.

The sensual quality of the voice carried social and political qualities. After NS newsreels and their acoustical martial heroism, the FRG's newsreel's voice intended to articulate the new national identity via a new civilized masculinity, purged of war's violence but self-assured and able to lead the audience. This gendered performance is ignored in the newsreel archives' written documentation; most commentary documents do not account for the sex of the speakers engaged. During my research in the NDW archive in Hamburg - in 1998/9, before digitalization-I could detect only few isolated segments narrated by female voices, all related to specific topics, for example Christmas, and men's fashion (cf. UFA WOCHENSCHAU ${ }^{7}$ Nr. 64, Nr. 69, 1957). When female talking heads started to appear regularly on television, the newsreel also tried to adapt to the desires of cinema owners and to engage "a really good female voice" (quoted in: Schwarz 2002: 181, translated by the author). As far as I know, a newsreel edition spoken by a female voice as the principal speaker was not produced in Hamburg until 1964.

The exclusion of the female voice, though not the female body, in the Western newsreels corresponded to the traditional bourgeois gender system. In the polarity of gendered characters (cf. Hausen 1976), women were

7 In 1956, distribution of WELT IM BILD was gradually transferred to the new UFA company, changing the name into UFA WOCHENSCHAU and restarting numbering. 
believed to lack by their nature properties necessary to fulfill the commentary's function such as authority, credibility and self-distance. Analysis and interpretation of the world had been defined anew and confirmed as a male task and privilege since the late $18^{\text {th }}$ century in Western Europe; corporeal embodiment of feelings was held to be the realm of female expression (cf. Prokop 1998: 176). The newsreel emerged before First World War, imbued with this gender ideology in its audiovisual vocabulary and production routines, carrying it all over the world. As women's mode of spectatorship was held to be "distracted" (cf. Kracauer 1927b), a female voice therefore could not lead the national audience safely through the newsreel's world trip, as it was believed that women were not able to deal with the attractions of foreign images appropriately. In 1964, a report entitled "Fräuleinwunder" characterized German women on the one hand as "self-conscious, cosmopolitan and beauty-conscious" - and on the other hand criticized them for being "open for national fashion news and for those of foreign nations" (UfA WOCHENSCHAU 411, translated by the author). The allegation of women's lack of patriotism, commonly heard in post-war years, reappeared in 1964, when it came to exercising purchasing power, like a temporarily repressed mantra. But with growing international interdependencies in the 1950s, addressing female audiences with national consumerism could be only a subliminal practice of soft protection for national textile industries.

In East Germany's newsreel DER AUGENZEUGE, women were part of the editorial team and female voices were engaged in a more general way (cf. Schwarz 2006: 210). Here the "world" was smaller, its socialist allure less seductive, and the bourgeois social division of labor had been officially abandoned. In the newsreel production team in Hamburg, women were engaged as cutters, archive specialists, and secretaries-as experts with specific and prestigious qualifications necessary for newsreel production and highly estimated in the team but with very limited or no editorial competence. They belonged to the new generation of young "beautiful women" in the late 1950 s and 1960s. In the film laboratory, so-called "Kopiermädchen" [copy girls] were engaged in boring manual labor at night to produce the film copies to be sent to cinema theatres. 


\section{National Production and Consumption}

Some examples are presented here of how relations between nation and gender have been operating at cross-sections of discourse and imagination. As topics like industrial production, advertisement and consumption (especially fashion and beauty) across borders are particularly susceptible to being gendered, most examples have been drawn from this realm.

Fig. 4: "Grapefruit-Queen”. NEUE DEUTSCHE WOCHENSCHAU Nr. 1, 1950.

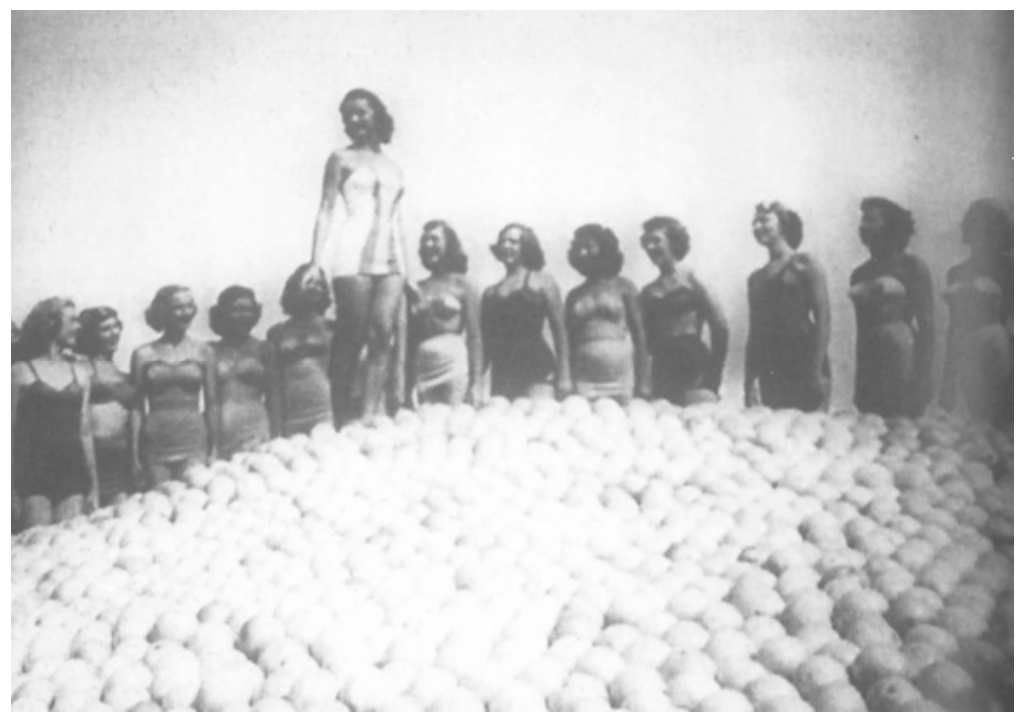

Source: Bundesarchiv

The first example concerns NDW's first reel from February 1950. It included a seemingly lighthearted beauty contest, with girls in swimming suits posing for a cinematographic American grapefruit advertisement (see Fig. 4). Yet the German commentary in this case did not "obey" conventions to read this advertisement in a way that was politically correct. Instead, in a harsh diction of voyeuristic misogyny ("nice rascals") it took symbolic revenge for what German women and the United States had inflicted on "us", thus constructing an image of the nation as male. The contemporary audience doubtlessly recognized the link to the girls and women among them who were believed to have exchanged "love for nylons" with allied occupa- 
tion soldiers. The newsreel commentary, playing with the visual content and potential of imported images, could manipulate these images into portraying different or contrary meanings before they were screened. Performing a "sadistic" masculine voyeurism, the NDW in its first edition constructed itself as a watchful weapon against the American persuasions of hedonistic pleasure. In cinema halls, this sujet was well received-although not in the advisory board, where the only female member withdrew in protest.

The second example relates to representation of the country's industrial production and economic success. A basic discursive feature of $1950 \mathrm{~s}$ newsreels in West Germany is the denial of women's contribution, ${ }^{8}$ which encouraged the perception of the economic miracle as a uniformly masculine performance. This has to be situated in the context: The postwar "rubble women", depicted in allied and licensed mass media, highlighted women's engagement in reconstruction, carrying also the message of masculine defeat, and this icon remained for some years an obsessive yet displaced part of collective memory (NDW 192, 1953). West Germany was also seeking to distance itself from "communist" GDR, accusing the "Zone" of destroying the family by forcing women to leave their home and venture into industrial workplaces. In the West, the family model of the male breadwinner for some children and wife/mother/Hausfrau, upset during the war and for some years after it, was reestablished. These ideological conditions made it impossible for women working in production and other industries to find themselves represented as discursively legitimate contributors to the nation's increasing prosperity.

This does not mean that women were not identifiable in the newsreel images, in shots taken at industrial workplaces, on factory work floors and in offices, laboratories, on the assembly line, as seamstresses, secretaries or nurses. ${ }^{9}$ But when they were represented in these real-life 'roles' they were portrayed not as 'actors', but as an accidentally existent, voiceless human part of the industrial inventory in which other actors prevailed. Women

8 Women's part of the labor workforce has been stable from late 19th century until to the 1970s in Germany/the old FRG at 36-37 percent; 48-50 percent of all women between 15 and 60 years old worked outside (with exceptions in war and post-war times; cf. Hausen 1997:31).

9 Insofar, images can be read as a "counter-analysis" (cf. Ferro 1977). 
were visible there but they were not made meaningful in their own right, neither in appearance nor in outspoken discourse. Yet they were meaningful for other discourses, for example that of unilaterally gendered social hierarchies at the workplace. This perception reflects one part of the truth, since for the majority of women in a segregated labor market only a few socially-acceptable professions were accessible (cf. Hausen 1997: 26).

A telling example of this practice is a news-film of 1955, screened for Müttergenesungswerk's [mother's recovery initiative] fundraising around Mother's Day. We see federal president Heuss visiting female workers seated at sewing machines on the factory floor of a company producing clothes for children, while the commentary insists on the entrepreneur's charity (WiB 148, 1955). The images may have been a consciously negotiated deviation from the ruling "system of sensual evidences": They showed women as acting industrial workers, however in laborious and poorly remunerated industrial jobs. This image sequence should provide evidence of the need to collect money to allow some weeks of rest cure for women overburdened by the tasks of both earning money and being mothers. The discourse constructed women as helpless objects of charity, although the company's charity politics being mentioned may have been the employer's condition for allowing the company's location to be made public. The other part of the truth in FRG's 1950 newsreel was skipped over: the palpable and far-reaching improvement in women's legal status, as adjustments of the Civil Code in 1953/1957 reduced privileges of husbands, e.g. a husband's right to block his wife's employment contract. ${ }^{10}$

\section{FASHION}

The third example concerns the strategic field of fashion. Showcase, exhibition, looking and being-looked-at: the newsreel exchange system followed imaginary logics similar to those of bourgeois prestige consumption and

10 The Fundamental Law from 1949 stipulates in Art 3, Abs 2 an encompassing equality in legal and social matters, as a result of a campaign led by female members of the Parlamentarischer Rat [Parliamentary Council] in 1948. By constitutional commitment, the conservative government was obliged to amendments of the Civil Code of 1901. 
haute couture. Newsreel's fashion-films displayed-at least theoreticallythe economic success and cultivated taste not of husbands and fathers but of nations, showing prosperity and development not of a social class but of the nations imagined collectively as the bourgeoisie. Only in NDW's first year could fashion appear as a field of female expertise, with designer Helle Brüns, mannequin Hildegard Knef or actress Hilde Weissner. By 1951, fashion news-films were narrated by a male voice, and on the screen male designers such as Heinz Oestergaard (Berlin) and Heinz Schulze-Varell (Munich) alone-maybe with allied help_were permitted to represent West German fashion excellence. In NDW's portrayal of foreign fashion, prominent male designers appeared as the only legitimate fashion experts, as kings and dictators represented or accompanied by ambassadors: breathtakingly opulent evening gowns with names, displayed by nameless slim women.

Fig. 5: Heinz Schulze-Varell's “architectural” fashion. NEUE DEUTSCHE WOCHENSCHAU Nr. 88, 1951.

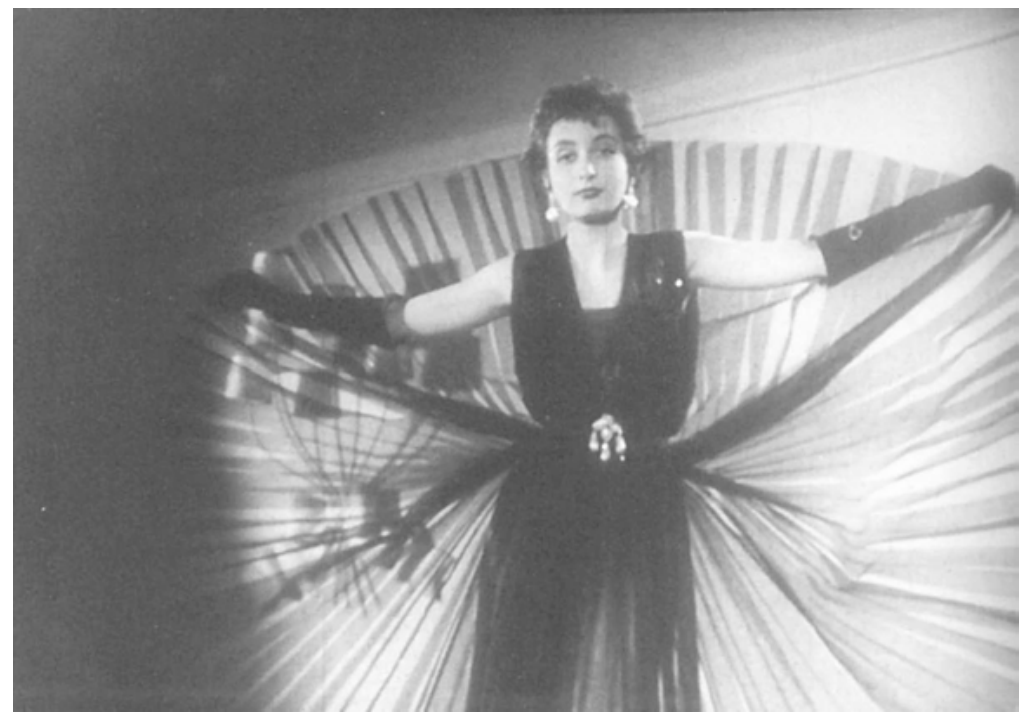

Source: Bundesarchiv

A French fashion show held in Hamburg was ennobled to the point of being portrayed as a diplomatic event entitled "Entente Modéale" (cf. Schwarz 
2002: 318-321), as West German stocking companies (OPAL, ARWA) cooperated with French and Italian fashion houses (Christian Dior, Jacques Fath and Emilio Schubert) for license-partnership. From 1951, and especially after Jacques Fath's sudden death in 1954, an increasing number of carefully elaborated news-films on German fashion transformed the "French" topic into a national one and the perception of German fashion into an export commodity competing with Haute Couture from Paris, Vienna and Milan. Fashion shoots of new collections-outstanding in length and cinematographic quality - occupied the first "national" program position (cf. NDW 88, 1951; NDW 113, 1952; WIB 133 and NDW 291, 1955; WIB 194, UfA 7, NDW 349, 1956; UfA 431, 1964). These carefully elaborated fashion shoots are still fascinating today.

In terms of audience, the newsreel always has been taken as a format offering something for everyone, and fashion as an instrument for addressing women. Indeed, fashion was named first preference by female cinemagoers in 1957 (cf. Schwarz 2002: 424); in the United States, fashion was everyone's second preference, after sports (Baechlin/Muller-Strauss 1951: 61). This high resonance among women as well as men of a topic which with "beauty" was less than 5 percent of a newsreel's film length (sports accounted for approx. 25 percent) indicates that one of the newsreel's most attractive features was the display of idealized bodies of both sexes. But fashion stories also symbolically constructed the fashionable woman as an icon representing plenitude and prosperity, erotic liberation and aesthetic self-fulfillment, as the phantasmagoric incarnation of Western democracies. The mannequin's body was, in the newsreel, a surface and stage of display, and to exhibit it was a symbol of market economy and its freedoms (Schwarz 2000:133). The advent of artificial fabrics partly changed the message in 1952, now informing the audience that women could themselves appropriate clothes made of artificial textile fibers produced by former IG Farben companies. Fashion designer Heinz Oestergaard was ready to process artificial fibres, awarding to these cheap fabrics the nimbus of Haute Couture. Instead of admiration and desire, appropriation and practice were the new messages, highlighting (national) consumption as "women's route to citizenship" (Carter 1997: 71).

The mannequins in the fashion shoots acted in front of the camera as translators of the messages the fashion houses wanted to convey to the public. Whereas the melodramatic femininities designed by Schulze-Varell did 
not break the rules of prestigious consumption, Oestergaard's dresses made the mannequins step out, in order to demonstrate the skirts" "swinging-up" movement: his dresses presupposed freedom - to walk and to work, to earn money for oneself and one's family. The new fabrics' imaginary tended to dissolve gender and class conflicts into a harmonized middle class society, countless happily (re)uniting heterosexual couples. Few label-free fashion stories left room for NDW's critical editorial comments, and textile mass marketing managers organized minor fashion shows which deliberately referenced this conflict. One fashion show on a scaffold at the courtyard of Maschinenbau Salzgitter $\mathrm{GmbH}$ confronted mannered bourgeois fashion with (male and female) blue collar workers "in silent dialogue with the pay packet", but showing the on-location audience finally applauding the mannequins (NDW 132, 1952, translated by the author). Another show was situated in a mine, "in order to demonstrate that the original material stems from the profundity of earth", depicting large-eyed blue-collar miners admiring mannequins in evening gowns (NDW 276, 1955; Schwarz 2002: 326 et seqq.). Both narratives insisted that fashion's hedonistic pleasures were in sharp opposition to the hard industrial work on which they rely; but the discourse about fashion as a socially reconciling power was supported by visual evidence.

\section{Beautiful Women and Motorized Servants}

The fourth example can be found in the work of the more progressive UFA WOCHENSCHAU, which, in 1964, held an outspoken discourse about the "beautiful women". Female beauty, in 19th century a "natural" quality of charming appearance which ennobled bourgeois husbands, now appeared to be attainable by every woman through fashion, cosmetics and a body language which could be learned via models from cinema and magazines (cf. UFA WOCHENSCHAU 411). In the postwar period, beauty was the newsreel's discursive code for the modern women who, legitimized by beauty, gained access to the public sphere, entering the workforce and engaging in other activities out of home and family-activities which put more emphasis on personal presentation than activities in the private sphere of the home. This discursive code claimed to implicitly disclose something about the nature of the social change of the period while describing appearances. 
In earlier decades, "beauty" as a topic in the newsreel had echoed scandal and provocation, when "beauty contests" with girls in swimsuits and evening gowns dramatized the provocation the modern woman constituted for conservative settings feeling endangered by upwardly mobile young women. The UfA Wochenschau in 1964 redeemed the notion of beauty, designing the new modern woman as a combination of non-glamourized professional activity and "beauty", a feminine, fashionable and appealing appearance, obtained by and necessary for professional careers. The provocative and irritating features of the 1920 s modern woman transgressing gender limits appeared to be overcome by a generalized and moderate, nontransgressing, practice.

The fifth example of how relations between nation and gender have been operating at cross-sections of discourse and imagination concerns aspects of the modern woman more difficult to integrate into the logic of conspicuous consumption. From the 1950s, the proliferation of domestic appliances in the home was a problem for the newsreel's representational logic. Washing machines and refrigerators were made for female use, but at home. The private sphere of the household, defined as the natural workplace of housewives, became the location of technical progress and its modern rationality. News-film segments on consumer fairs showed new kitchen aids, and the 'hostess as housewife' mannequin displayed not only her fashionable outfit but also manipulated "motorized servants" (NDW 378,1957 , translated by the author). This discourse imbued the housewife with the ideas of power and leisure time. Some newsreel commentaries skeptically observed this transformation, worrying about "housewives' phlegm" (NDW 4, 1950, translated by the author) or devaluating modern housework as "foolproof" (NDW 375, 1957, translated by the author). We may recognize in this metaphor, which bemoans the de-valuation of women's "housework by love" a coded discursive bridge to the idea of men taking over household chores themselves. Technical household progress affected the power balance between men and women at home and carried the idea of women's entrance into the workforce, as a second income in most cases was needed to realize the household's modernization. 
Fig. 6: Studio shooting of men's fashion. UFA WOCHENSCHAU Nr. 323, 1962.

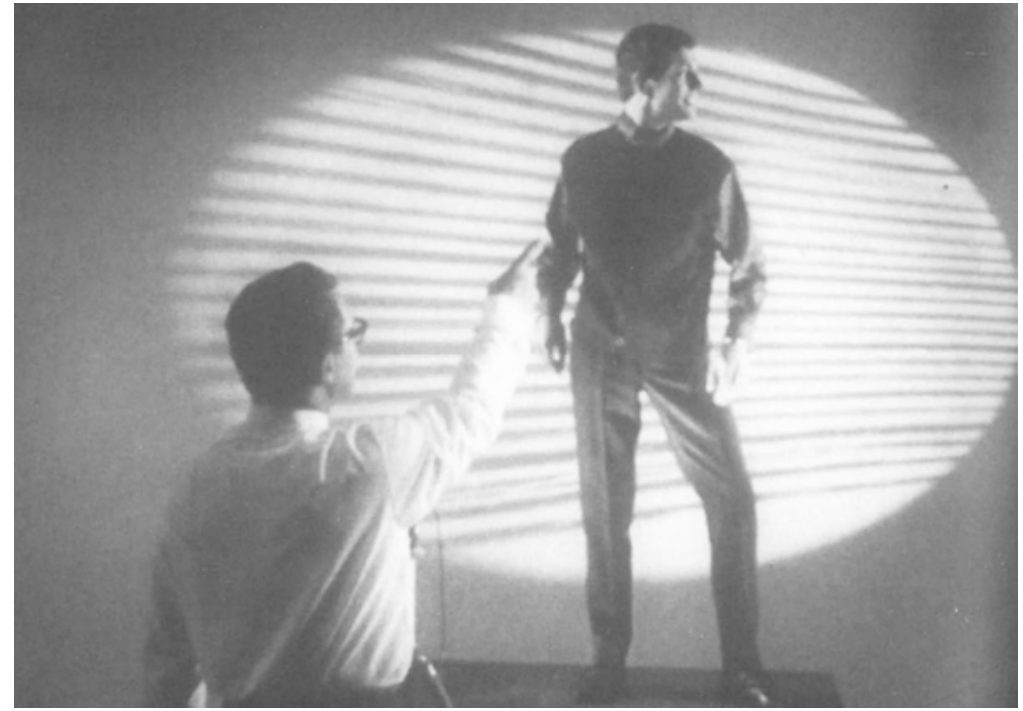

Source: Bundesarchiv

Whereas the FRG's state-newsreel did not encompass a particular and distinct representation of male workers or employees, the GDR's AUGENZEUGE offered a stage to industrial workers, promoting the working class as the central political class of socialist society, with the camera entering workplaces depicting individual workers and their performances (cf. Schwarz 2006: 213 et seqq.). The West German government did not intend to strengthen representation of the working class. Especially in the ongoing conflict over industrial power sharing between the government, employers and unions, the government's newsreel preferred to represent the nation's productivity by focusing on economic leaders, minister Ludwig Erhard, and directors of big industrial plants-or by displaying production results, goods and commodities, in news-film about the Hannover fair and automobile fairs in Frankfurt, Paris or Geneva. While blue-collar work clearly lost value in economic and representational terms, as could be observed in a news-film on the European coal-mine crisis (UFA WocHENSCHAU 136, 1958), nonproductive industries gained weight and prestige as carriers of presentation and representation-in which "beautiful" women could be 
successful. Masculine identities felt endangered by the loss of privilege, and the newsreel reluctantly recorded this shifting power balance as a cinematographic yellow press impregnated by social melancholy. As men exclusively held and exerted authority over the images (cameramen), discourses (editor-in-chief) and voices (speaker) presented, the newsreel could articulate this discomfort in dark cinema halls, protected from daylight. This has to be taken into account when looking to the newsreel of the 1950s as "a visibility machine" (Sieber 2011: 303, translated by the author). Men's fashion and male hedonism started to be legitimized as a national product in 1962 .

\section{A New Documentary Style}

The genre's 'misogyny' was also driven by the advent of television in the 1950s, already endangering the newsreel's raison d'être. In 1953, journalist Ella Reetz commented ironically on the newsreel reporter: within a hilarious bestiary she would class him as a blind beastie only geared to noise: "For them, only screaming sounds are topical ... Let us dim out and wait for the de-masculinized newsreel. Yes, how about the profession of a female newsreel reporter?" (quoted in: Schwarz 2002: 441, translated by the author)

This hope, inspired by television, remained unfulfilled. However, intensified competition with TAGESSCHAU [DAILY NEWS] broadcast daily since the end of 1956, progress in recording techniques, and a new generation of editors triggered modernization, giving more weight to local sujets and to the spoken discourse. The pre-editorial position of the cameraman shooting public events was relativized. Editors developed exposés and started to appear interviewing 'people like you and me', on streets, in supermarkets, and in citizens' homes. Now, sensual evidence was produced to support a commentary's argument, hammering together fresh shots and images from the newsreel's archive: montage became more important. ${ }^{11}$ Fewer and longer single news-film, sometimes extended to an essayistic style, filled up the eleven minutes (often less). The government's representation decreased

11 In the 1960s, cutter could perform more complex tasks and take over more editorial responsibility. 
in proportion and quality, and news-films on sports now took notice of disciplines still untouched by the commercialization of leisure time.

This event-detached documentary style changed the newsreel's "sensual police" character, its "apportionment/distribution of the sensual" and the "system of evidences" (cf. Rancière 2006: 25 et seqq.; Sieber 2012: 44 et seqq., translations by the author). On the one hand, federal ministries and institutions represented in the advisory board gained still more influence over editorial choices, as well the interests of companies in covert advertising (cf. Lehnert 2013: 370-379). On the other hand, with the newsreel's decline the pressure to reproduce reality decreased, offering new choices in both topic and approach. Some editions of this period, from 1959 to 1964, are comprised of essayistic features, and through their image-discourserelation we can retrace how the representation of the shifting cultural identity was accompanied by imaginary operations. For example, in a story on young peoples' musical tastes (NDW 590, 1961), black jazz was discursively appropriated as a style preferred by educated young male Germans; on the level of montage, black men-identified with wild jazz in early 1950s - now appeared connected with traditional European music styles on the screen. Silent, imaginary spatial re-organizations were at work and maybe even consciously applied. Access to this part of history is not in paper archives; but can be found only in the audiovisual material itself.

\section{References}

Baechlin, Peter/Muller-Strauss, Maurice (1951): La presse filmée dans le monde, Paris: UNESCO.

Baechlin, Peter/Muller-Strauss, Maurice (1952): Newsreels Across the World, Paris: UNESCO, available at: http://unesdoc.unesco.org/images/ 0003/000301/030104eo.pdf [June 15 2016].

Carter, Erica (1997): How German Is She? Postwar West German Reconstruction and the Consuming Women, Ann Arbor: University of Michigan Press.

Chartier, Roger (1989): “Le monde comme representation”. In: Annales ESC 6: pp. 1505-1520. 
Diehl, Paula (2012): "Über Emotion, Affekt und Affizierung in der Politik”. In: Felix Heidenreich/Gary S. Schaal (eds.), Politische Theorie und Emotionen. Baden-Baden: Nomos, pp. 155-176.

Eder, Franz X. (2008): “Auf die 'gesunde Sinnlichkeit' der Nationalsozialisten folgte der Einfluss der Amerikaner": Sexualität und Medien vom Nationalsozialismus bis zur Sexuellen Revolution. In: zeitenblicke 7, 3. available at: http://www.zeitenblicke.de/2008/3/eder/index_ html\#d57e182 [June 15 2016].

Ferro, Marc (1977): "Der Film als 'Gegenanalyse' der Gesellschaft." In: Claudia Honegger (ed.), Schrift und Materie der Geschichte. Vorschläge zur systematischen Aneignung historischer Prozesse, Frankfurt a.M.: Suhrkamp, pp. 247-271.

Foucault, Michel (1980): “The confessions of the flesh.” In: Colin Gordon (ed.), Power/Knowledge. Selected Interviews and Other Writings 19721977, New York: Pantheon, pp. 194-228.

Griep, Karl (1996): "Newsreel contracts of the Bundesarchiv-Filmarchiv." In: Roger Smither/Wolfgang Klaue (eds.), Newsreels in Film Archives. A Survey Based on the FIAF Newsreel Symposium, Trowbridge: FIAF. Gottgetreu, Sabine (1992): Der bewegliche Blick. Zum Paradigmenwechsel in der feministischen Filmtheorie, Frankfurt a.M.: Lang.

Hagemann, Walter (1959) (ed.): Filmbesucher und Wochenschau. Emsdetten: Lechte.

Hausen, Karin (1976): “Die Polarisierung. der 'Geschlechtscharaktere' Eine Spiegelung der Dissoziation von Erwerbs- und Familienleben.” In: Werner Conze (ed.), Sozialgeschichte der Familie in der Neuzeit Europas: Stuttgart, pp. 363-393.

Hausen, Karin (1997): "Frauenerwerbstätigkeit und erwerbstätige Frauen. Anmerkungen zur historischen Forschung." In: Gunilla-Friederike Budde (ed.), Frauen arbeiten. Weibliche Erwerbstätigkeit in Ost- und Westdeutschland nach 1945, Göttingen: Vandenhoeck, pp. 9-45.

King, Angela (2004): "The Prisoner of Gender: Foucault and the Disciplining of the Female Body. "In: Journal of International Women's Studies, 5(2), 29-39. Available at: http://vc.bridgew.edu/jiws/vol5/iss2/4 [June 15 2016].

Kracauer, Siegfried (1927a, 1996): “Die Photographie.” In: Johanna Rosenberg (ed.), Der verbotene Blick. Beobachtungen-AnalysenKritiken, Leipzig: Reclam, pp. 185-203. 
Kracauer, Siegfried (1927b, 1996): "Die kleinen Ladenmädchen gehen ins Kino.” In: Johanna Rosenberg (ed.), Der verbotene Blick. Beobachtungen-Analysen-Kritiken, Leipzig: Reclam, pp. 156-171.

Leache, Patricia Amigot/Margot Pujal i Llombart (2011): “A reading of gender as a dispositif of power." In: Revista Pequén 1, 1, pp. 1-26, available at: http://www.ubiobio.cl/miweb/webfile/media/265/A\%20 reading $\% 20$ of $\% 20$ gender\%20as\%20a\%20dispositif.pdf [June 15 2016].

Lehnert, Sigrun (2013): Wochenschau und Tagesschau in den 1950er Jahren, Konstanz, München: UVK.

Prokop, Ulrike (1998): "Die Funktion der Literatur für die Selbstthematisierung von Weiblichkeit im ausgehenden 18. Jahrhundert." In: Aleida Assmann/ Heidrun Friese (eds.), Identitäten. Erinnerung, Geschichte, Identität 3. Frankfurt a.M.: Suhrkamp, pp. 166-180.

Prommer, Elizabeth Anna (2010): “Das Kinopublikum im Wandel.” In: Patrick Glogner/Patrick S. Föhl (eds.), Das Kulturpublikum. Fragestellungen und Befunde der empirischen Forschung. Wiesbaden: Verlag für Sozialwissenschaften, pp. 195-238.

Rancière, Jacques (2006): Die Aufteilung des Sinnlichen. Die Politik der Kunst und ihre Paradoxien (Orig. Le partage du sensible; esthétique et politique 2000). Berlin: B_Books.

Schwarz, Uta (2000): "Perlon - Der Stoff der neuen Harmonie. Eine geschlechtergeschichtliche Lektüre bundesdeutscher Wochenschauen der fünfziger Jahre." In: traverse 3, pp. 132-142.

Schwarz, Uta (2001): "Wochenschauen als Quellen einer Kulturgeschichte des Sozialen. Die Kategorie Geschlecht in den bundesdeutschen Wochenschauen der fünfziger Jahre.” In: Archiv für Sozialgeschichte 41: pp. 271-296.

Schwarz, Uta (2002): Wochenschau, westdeutsche Identität und Geschlecht in den fünfziger Jahren, Frankfurt/Main: Campus.

Schwarz, Uta (2003): “ “ $\ldots$ angenehm in der Bar zu tragen, unangenehm in bar zu bezahlen'. Unterhaltungsbeiträge in bundesdeutschen Wochenschauen der 1950er Jahre als Quellen der Sozialgeschichte." In: Moshe Zuckermann (ed.), Medien-Politik-Geschichte. Tel Aviver Jahrbuch für deutsche Geschichte XXXI. Göttingen: Wallstein, pp. 187-207.

Schwarz, Uta (2006): "Der blockübergreifende Charme dokumentarischer Bilder: Tradition, Ideologie und Geschlecht in der Repräsentationsordnung der bundesdeutschen und der DDR-Wochenschau der 1950er 
Jahre." In: Thomas Lindenberger (ed.), Massenmedien im Kalten Krieg. Akteure, Bilder, Resonanzen. Köln u.a. Böhlau, pp. 203-234.

Sieber, Samuel (2011): "Zur Politik medialer Dispositive." In: Nadja Borer/Samuel Sieber/Georg Christoph Tholen (eds.): Blickregime und Dispositive audiovisueller Medien, Bielefeld: Transcript, pp. 295-310.

Sieber, Samuel (2012): "Mediale Dispositive der politischen Kommunikation. In: Felix Heidenreich/Daniel Schönpflug (eds.), Politische Kommunikation: Von der klassischen Rhetorik zur Mediendemokratie/La communication politique: de la rhétorique classique à la démocratie des médias, Berlin: Lit Verlag, pp. 39-51.

Stamm, Karl (1987): "German Wartime Newsreels (Deutsche Wochenschau): the problem of 'authenticity." In: Historical Journal for Film, Radio, and Television 7,3, pp. 239-245.

Walker, Horst O. (1982): Das Presse- und Informationsamt der Bundesregierung. Frankfurt a.M.: Haag und Herchen.

Von Hase, Karl-Günther (1988) (ed.), Konrad Adenauer und die Presse, Bonn: Stiftung Bundeskanzler-Adenauer-Haus.

Wolfrum, Edgar (2004): “Konrad Adenauer.” In: Frank Möller (ed.), Charismatische Führer der deutschen Nation, München: R. Oldenbourg Verlag 2004, pp. 171-191. 